УДК 349.3

DOI https://doi.org/10.32837/pyuv.v0i2(31).567

М. Ю. Сохань

orcid.org/0000-0002-8132-3121

аспірантка кафедри цивільно-правових дисииплін, господарського та трудового права

Харківського національного педагогічного університету імені Г.С.Сковороди

\title{
ЗАГАЛЬНООБОВ'ЯЗКОВЕ ДЕРЖАВНЕ СОЦІАЛЬНЕ СТРАХУВАННЯ ЯК ФОРМА СОЦІАЛЬНОГО ЗАХИСТУ ОСІБ ІЗ СІМЕЙНИМИ ОБОВ'ЯЗКАМИ
}

Постановка проблеми. Відповідно до ст. 46 Конституції України [1] громадяни мають право на соціальний захист, що включає право на забезпечення їх у разі повної, часткової або тимчасової втрати працездатності, годувальника, безробіття з незалежних від них обставин, а також у старості та в інших передбачених законом випадках. Це право гарантується загальнообов'язковим державним соціальним страхуванням за рахунок страхових внесків громадян, підприємств, установ та організацій, а також бюджетних та інших джерел соціального забезпечення, створенням мережі державних, комунальних, приватних закладів для догляду за непрацездатними. Реалізація такого права на практиці - це забезпечення достатнього рівня добробуту громадянам держави, що відповідає міжнародним умовам, а саме ст. 22 Загальної декларації прав людини 1948 р. і ст. 9 Міжнародного пакту про економічні, соціальні та культурні права 1966 р., з яких випливає, що держави визнають право кожної людини на соціальний захист, включаючи соціальне страхування. Останнє є важливою частиною соціального захисту населення, центром якого є людина та її потреби, а якість їх задоволення впливає на соціально-економічний розвиток держави. Страхування створює умови для відтворення робочої сили та захисту громадян у разі настання певних страхових випадків: втрати працездатності, втрати годувальника, безробіття, нещасного випадку на виробництві тощо.

Мета статті - розглянути загальнообов'язкове державне соціальне страхування як одну із форм соціального захисту таких суб'єктів соціального забезпечення, як особи із сімейними обов'язками, на підставі чого зробити відповідні висновки.

Аналіз останніх досліджень і публікацій. Соціальне страхування завжди перебувало у центрі уваги вчених-правознавців. Різні його аспекти досліджували В.М. Андріїв, Д.В. Божко, Н.Б. Болотіна, К.В. Бориченко, О.С. Бурлака, О.В. Москаленко, О.В. Пономаренко, С.М. Прилипко, I.М. Сирота, Б.І. Сташків, О.Г. Чутчева, O.М. Ярошенко та ін.

Виклад основного матеріалу. Однією з організаційно-правових форм соціального захисту осіб із сімейними обов'язками є загальнообов'язкове державне соціальне страхування, яке здійснюється в рамках загальнообов'язкового державного соціального страхування у зв'язку з тимчасовою втратою працездатності, від нещасного випадку на виробництві та професійного захворювання, які спричинили втрату працездатності, а також пенсійного страхування.

Суть будь-якого виду страхування полягає у зменшенні й компенсації ризику матеріальних втрат шляхом розподілу його негативних наслідків між всіма суб'єктами, схильними до певних видів ризику. Ризик у соціальній сфері виникає, коли має місце невизначеність: а) немає однозначних чітких уявлень про процеси і явища; б) відбуваються постійні зміни умов діяльності переорієнтація виробництва, кон'юнктури ринку та ін.; в) неможливо встановити й точно спрогнозувати наслідки впливу на об'єкти та явища певних чинників (науково-технічного прогресу, стихійного лиха, поведінки конкурентів і споживачів), оцінити майбутній розвиток подій; г) бракує повної інформації про внутрішні й зовнішні умови прийняття рішень або існуе неточна чи суперечлива інформація щодо об'єкта (явища) і його середовища; д) існує певна асиметрія належних відомостей, тобто нерівний ступінь поінформованості суб'єктів про умови їхньої діяльності; е) виникає множинна критеріальність і конфліктність в оцінці рішень, коли доводиться свідомо йти на компроміси [2]. У цих цілях суб'єкти формують матеріальні ресурси для їх цільового використання за настання страхового випадку, тобто події, з настанням якої виникає право застрахованої особи на отримання матеріального забезпечення або соціальних послуг, передбачених законами України 3 окремих видів загальнообов'язкового державного соціального страхування. До таких випадків, із настанням яких надаються матеріальне забезпечення та соціальні послуги, належать: а) тимчасова непрацездатність; б) вагітність і пологи; в) інвалідність; г) хвороба; д) досягнення пенсійного віку; е) смерть годувальника; є) безробіття; ж) соціальні послуги; інші матеріальні витрати; пов'язані з певними обставинами; з) нещасний випадок на виробництві; и) професійне захворювання. 
Тимчасова непрацездатність - це непрацездатність особи внаслідок захворювання, травми або 3 інших причин, що не залежить від факту втрати працездатності (пологів, карантину, догляду за хворим тощо), яка має тимчасовий зворотний характер під впливом лікування та реабілітаційних заходів, триває до відновлення працездатності або встановлення групи інвалідності, а в разі інших причин - до закінчення причин відсторонення від роботи. Метою надання матеріальної допомоги по тимчасовій непрацездатності є заміна втраченого з поважних причин заробітку. Як зазначає Д. Божко, загальнообов'язкове державне соціальне страхування у зв'язку з тимчасовою втратою працездатності - це гарантована державою система прав та обов'язків, що передбачає у випадках тимчасової непрацездатності, вагітності й пологів, смерті, перенесених захворювань і травм у порядку, в розмipax i на умовах, установлених законодавством, матеріальне забезпечення й надання соціальних послуг за рахунок коштів Фонду соціального страхування України, що формуються шляхом сплати страхових внесків, а також із інших передбачених законом джерел [3, с. 123]. До суттєвих ознак загальнообов'язкового державного соціального страхування у зв'язку з тимчасовою втратою працездатності дослідниця відносить: а) це організаційно-правова форма соціального забезпечення осіб, які тимчасово втратили працездатність; б) воно зумовлено тимчасовою непрацездатністю обставиною, внаслідок якої застрахована особа або члени їі сім'ї можуть втратити засоби для свого існування і змушені отримувати матеріальне забезпечення й соціальні послуги; в) становить систему прав та обов'язків у відповідній сфері; г) при страхуванні реалізацію застрахованими особами своїх прав у цій царині гарантує держава; г) воно полягає в наданні матеріального забезпечення й соціальних послуг у випадках, порядку, в розміpax i на умовах, установлених законодавством; д) обов'язок із надання застрахованим особам матеріального забезпечення й соціальних послуг бере на себе Фонд соціального страхування України.

Відповідно до ст. 20 Закону України «Про загальнообов'язкове державне соціальне страхування» [4] видами матеріального забезпечення та соціальних послуг за страхуванням у зв'язку з тимчасовою втратою працездатності є: допомога по тимчасовій непрацездатності (включаючи догляд за хворою дитиною); допомога по вагітності та пологах; допомога на поховання (крім поховання пенсіонерів, безробітних та осіб, які померли від нещасного випадку на виробництві); оплата лікування в реабілітаційних відділеннях санаторно-курортного закладу після перенесених захворювань і травм.

Так, згідно із ч. 3 ст. 22 указаного Закону допомога по тимчасовій непрацездатності по догляду за хворою дитиною віком до 14 років виплачується застрахованій особі з першого дня за період, протягом якого дитина за висновком лікаря потребує догляду, але не більш як за 14 календарних днів. Якщо ж дитина потребує стаціонарного лікування, то допомога виплачується застрахованій особі з першого дня за весь час перебування у стаціонарі разом із хворою дитиною. Застрахованим особам, які працюють на сезонних і тимчасових роботах, у разі хвороби дитини віком до 14 років допомога по тимчасовій непрацездатності призначається і виплачується не більше як за 75 календарних днів протягом календарного року. Втім, згідно із ч. 6 вказаної статті допомога по тимчасовій непрацездатності по догляду за хворою дитиною віком до 14 років і в разі захворювання матері або іншої особи, яка фактично здійснює догляд за дитиною віком до трьох років або дитиною-інвалідом віком до 18 років, не надається, якщо застрахована особа перебувала тоді у щорічній (основній чи додатковій) відпустці, додатковій відпустці у зв'язку із навчанням або творчій відпустці.

Іншим видом матеріального забезпечення та соціальних послуг за страхуванням у зв'язку 3 тимчасовою втратою працездатності, на якому також слід акцентувати увагу, є допомога по вагітності та пологах. Підставою для призначення цієї допомоги виступає особливий стан жіночого організму, пов'язаний із виконанням нормальної фізіологічної функції - пологів. Так, відповідно до ч. 1 ст. 25 Закону України «Про загальнообов'язкове державне соціальне страхування» допомога по вагітності та пологах надається застрахованій особі у формі матеріального забезпечення, яке компенсує втрату заробітної плати (доходу) за період відпустки у зв'язку з вагітністю та пологами. Допомога по вагітності та пологах застрахованій особі виплачується за весь період відпустки у зв'язку з вагітністю та пологами, тривалість якої становить 70 календарних днів до пологів і 56 (у разі ускладнених пологів або народження двох чи більше дітей - 70) календарних днів після пологів.

Згідно з листом Міністерства праці та соціальної політики України від 23 травня 2008 р. за № 273/020/99-08 [5] із дня, зазначеного у листку непрацездатності, виданого у зв'язку з вагітністю та пологами, застрахована особа перебуває у відпустці у зв'язку з вагітністю та пологами, і саме 3 цього дня у застрахованої особи виникає право на одержання допомоги по вагітності та пологах. Таким чином, страховий випадок у застрахованої особи виникає із дня надання відпустки у зв'язку з вагітністю та пологами за медичним висновком, зазначеним у листку непрацездатності, а не з дня, коли застрахована особа вирішила припинити працювати і піти у зазначену відпустку за власною заявою. Скористатися своїм правом на матеріальне забезпечення, тобто звернутися по призначення допомоги, чи продовжувати працювати 
ще деякий час після надання відпустки у зв'язку з вагітністю та пологами - застрахована особа вирішує особисто. У будь-якому випадку, у разі звернення такої особи по призначення допомоги, розрахунковим періодом, за який обчислюється середня заробітна плата для розрахунку допомоги по вагітності та пологах, відповідно до Порядку обчислення середньої заробітної плати (доходу) для розрахунку виплат за загальнообов'язковим державним соціальним страхуванням, затвердженого постановою Кабінету Міністрів України від 26 вересня 2001 р., № 1266 [6] зі змінами, є останні 12 календарних місяців (із першого до першого числа), що передують місяцю, в якому настав страховий випадок, тобто місяцю, в якому у застрахованої особи настало право на відпустку у зв'язку з вагітністю та пологами за медичним висновком.

Дуже цікавим і позитивним щодо тривалості відпусток у зв'язку з вагітністю та пологами є зарубіжний досвід, наприклад, заслуговує на увагу досвід Франції, за законодавством якої встановлено диференціацію тривалості оплачуваної відпустки у зв'язку з вагітністю та пологами, а отже, і розміру відповідної допомоги залежно від кількості дітей у родині. Так, відповідно до законодавства Франції допомога у зв'язку з вагітністю і пологами виплачується у розмірі $100 \%$ доходу жінки протягом 6 тижнів (42 календарних дні) до та 10 тижнів (70 календарних днів) після народження першої дитини, 8 тижнів (56 календарних днів) до та 18 тижнів (126 календарних днів) після народження другої та наступних дітей [7, с. 120].

Підтримуючи позиції інших науковців із досліджуваної проблематики, пропонуємо запровадити відповідний зарубіжний досвід, і до законодавства нашої держави і встановити диференціацію тривалості оплачуваної відпустки у зв’язку з вагітністю та пологами не тільки залежно від категорії жінок (чорнобильці), складності пологів, народжуваності одночасно декількох дітей, а й від кількості дітей у родині. Зокрема, визначити, що допомога у зв'язку з вагітністю і пологами виплачується протягом 70 календарних днів до та 56 календарних днів після народження першої дитини; 84 календарних дні до та 70 календарних днів після народження другої дитини; 98 календарних днів до та 84 календарних днів після народження третьої та наступної дитини (за наявності на утриманні відповідно однієї чи більше дітей) [8, с. 168].

Важливою ознакою матеріального забезпечення та соціальних послуг у рамках загальнообов'язкового державного соціального страхування у сфері соціального захисту осіб із сімейними обов'язками є джерела їх фінансування, основними з яких відповідно до ст. 20 Основ законодавства України про загальнообов'язкове державне соціальне страхування [9] є внески роботодавців і застрахованих осіб. До формування коштів Фонду соціального страхування України за ст. 11 Закону України «Про загальнообов'язкове державне соціальне страхування» залучаються також суми фінансових санкцій, застосованих до підприємств, установ, організацій і фізичних осіб - підприємців за порушення встановленого порядку сплати страхових внесків, штрафів за недотримання законодавства про соціальне страхування, а також суми адміністративних штрафів, накладених відповідно до закону на посадових осіб і громадян за такі порушення; доходи від розміщення тимчасово вільних коштів, у т. ч. резерву коштів Фонду; добровільні внески та інші надходження відповідно до закону.

За чинним національним законодавством єдиним критерієм, від якого залежить розмір допомоги по тимчасовій непрацездатності, є страховий стаж особи, причому вказаний розмір не залежить від тривалості непрацездатності. Визнаючи, що кожна людина має відповідні права на соціальний захист і охорону здоров'я, забезпечення їх належної реалізації є пріоритетним напрямом діяльності суспільства й держави.

Висновки. Підводячи підсумок вищенаведеному, слід зазначити, що загальнообов'язкове державне соціальне страхування як форма соціального захисту осіб із сімейними обов'язками $є$ основною матеріальною гарантією реалізації їхнього права на соціальний захист у разі тимчасової втрати ними працездатності. Це система прав, обов'язків і гарантій, яка передбачає надання соціального захисту осіб із сімейними обов'язками, що включає матеріальне забезпечення у зв'язку з вагітністю та пологами, а також у разі хвороби дитини, догляду за дитиною віком до 3 років або дитиною-інвалідом віком до 18 років у разі хвороби матері або іншої особи, котра доглядає за цією дитиною, втратою годувальника та соціальні послуги за рахунок грошових фондів, що формуються шляхом сплати страхових внесків власником або уповноваженим ним органом, громадянами, а також бюджетних та інших джерел, передбачених законом. Його головна суть і призначення зводяться до отримання застрахованою особою в разі настання страхового випадку від страховика матеріального забезпечення і соціальних послуг за рахунок страхувальника.

\section{Jimepamypa}

1. Конституція України від 28 червня 1996 р. № 254к/96-ВР. Відомості Верховної Ради України. 1996. № 30. Ст. 141.

2. Власенко Н.С. Правові засади системи інформаційного забезпечення соціальної політики. Демографія та соціальна політика. 2007. № 1. С. 159-169.

3. Божко Д.В. Правовідносини із загальнообов'язкового державного соціального страхування у зв'язку 3 тимчасовою втратою працездатності : дис. ... канд. юрид. наук : 12.00.05. Харків, 2017. 244 с. 
4. Про загальнообов'язкове державне соціальне страхування : Закон України від 23 вересня 1999 р. № 1105-XIV. Відомості Верховної Ради України. 1999. № 46-47. Ст. 403.

5. Щодо виплати допомоги по вагітності та пологах : лист Міністерства праці та соціальної політики України від 23 травня 2008 р. № 273/020/99-08. URL: http://search.ligazakon.ua/1_doc2.nsf/link $1 /$ FIN37962.html.

6. Про обчислення середньої заробітної плати (доходу, грошового забезпечення) для розрахунку виплат за загальнообов'язковим державним соціальним страхуванням : постанова Кабінету Міністрів України від 26 вересня 2001 р. № 1266 . URL: https://zakon.rada. gov.ua/laws/show/1266-2001-\% D0\% BF

7. Пономаренко О.В., Носов А.Д. Соціально-правовий захист дітей та молоді з особливими потребами в Україні. Вісник Запорізького національного універси тету. Педагогічні науки. 2010. Вип. 2(13). С. 113-120.

8. Бурлака О.С. Проблеми соціального захисту, сім'ї, дитинства, материнства та батьківства в Україні : дис. ... докт. юрид. наук : 12.00.05. Київ, 2019. 419 с.

9. Основи законодавства України про загальнообов'язкове державне соціальне страхування від 14 січня 1998 р. № 16/98-ВР. Відомості Верховної Ради Украӥни. 1998. № 23. Ст. 121.

\section{Анотація}

Сохань М. Ю. Загальнообов'язкове державне соціальне страхування як форма соціального захисту осіб із сімейними обов'язками. - Стаття.

У статті розглянуто загальнообов'язкове державне соціальне страхування як одну із форм соціального захисту таких суб'єктів соціального забезпечення, як особи із сімейними обов'язками, на підставі чого зроблено відповідні висновки. Зроблено висновок, що загальнообов'язкове державне соціальне страхування як форма соціального захисту осіб із сімейними обов'язками є основною матеріальною гарантією реалізації їхнього права на соціальний захист у разі тимчасової втрати ними працездатності. Це система прав, обов'язків і гарантій, яка передбачає надання соціального захисту осіб із сімейними обов'язками, що включає матеріальне забезпечення у зв'язку з вагітністю та пологами, а також у разі хвороби дитини, догляду за дитиною віком до 3 років або дитиною-інвалідом віком до 18 років у разі хвороби матері або іншої особи, котра доглядає за цією дитиною, втратою годувальника та соціальні послуги за рахунок грошових фондів, що формуються шляхом сплати страхових внесків власником або уповноваженим ним органом, громадянами, а також бюджетних та інших джерел, передбачених законом. Його головна суть і призначення зводяться до отримання застрахованою особою в разі настання страхового випадку від страховика матеріального забезпечення і соціальних послуг за рахунок страхувальника.

Зазначено, що важливою ознакою матеріального забезпечення та соціальних послуг у рамках загаль- нообов'язкового державного соціального страхування у сфері соціального захисту осіб із сімейними обов'язками є джерела їх фінансування, основними з яких відповідно до чинного законодавства є внески роботодавців і застрахованих осіб. Єдиним критерієм, від якого залежить розмір допомоги по тимчасовій непрацездатності, законодавство визнає страховий стаж особи, причому вказаний розмір не залежить від тривалості непрацездатності. Визнаючи, що кожна людина має відповідні права на соціальний захист і охорону здоров’я, забезпечення їх належної реалізації є пріоритетним напрямом діяльності суспільства й держави.

Ключові слова: держава, сім'я, соціальний захист, соціальне страхування, тимчасова непрацездатність, соціальні послуги, матеріальне забезпечення.

\section{Summary}

Sokhan M. Yu. Compulsory state social insurance as a form of social protection for persons with family responsibilities. - Article.

The article considers the obligatory state social insurance as one of the forms of social protection of such subjects of social security as persons with family responsibilities, on the basis of which the corresponding conclusions are made. It is concluded that compulsory state social insurance as a form of social protection of persons with family responsibilities is the main material guarantee of the realization of their right to social protection in case of temporary disability. It is a system of rights, responsibilities and guarantees, which provides for the provision of social protection for persons with family responsibilities, including material support in connection with pregnancy and childbirth, as well as in case of illness, care for a child under three years or a disabled child under the age of 18 in case of illness of the mother or other person caring for this child, loss of a breadwinner and social services at the expense of funds formed by paying insurance premiums by the owner or his authorized body, citizens and budget and other sources provided by law. Its main essence and purpose are reduced to receipt by the insured person in case of an insured event from the insurer of material support and social services at the expense of the insured.

It is noted that an important feature of material security and social services in the framework of compulsory state social insurance in the field of social protection of persons with family responsibilities are their sources of funding, the main of which, according to current legislation are contributions of employers and insured persons. The only criterion on which the amount of temporary disability benefits depends is recognized by law as the person's insurance record, and this amount does not depend on the duration of disability. Recognizing that everyone has the appropriate rights to social protection and health care, ensuring their proper implementation is a priority of society and the state.

Key words: state, family, social protection, social insurance, temporary disability, social services, material security. 